\title{
The Influence of Account Officer Development on the Smoothness of Murabahah Financing Returns (Case Study at Bank Syariah Mandiri, Bandar Lampung, Indonesia)
}

\author{
Hendra Novian ${ }^{1}$ \\ \{hnfarras@gmail.com $\left.{ }^{1}\right\}$ \\ Graduate Program of Raden Intan Lampung Islamic State University, Indonesia ${ }^{1}$
}

\begin{abstract}
The banking sector is very important for the progress of the country. This is because banks have financing products which are one of the most important sources of funds for any type of business, especially, the banking business is growing and entering the sharia banking business. The syari'ah banking system offers bank financing options that are more profitable for the small and medium business sector. but still have the risk of failure to return financing. This research was conducted at Bank Mandiri Syariah, Bandar Lampung City, Indonesia. The study was conducted to see whether the guidance of the Account Officer has an influence on the return of financing by customers. The results showed that coaching by the Account Officer had an effect on returns by customers in Bank Mandiri Syariah, Bandar Lampung City.
\end{abstract}

Keywords: Account Officer, Sharia Banking Business

\section{Introduction}

In the development of the banking world, the sector of sector financing is very important for the progress of the country [1]. This is because financing is one of the most important sources of funds for any type of business, especially, the banking business is growing and entering the sharia banking business. Banking activities in terms of channeling public funds are partly carried out in the form of goods or services provided to customers.

Then, to improve banking services to the public, it is necessary to develop bank activities that can meet people's needs, one of which is banking products with the principle of profit sharing. The principle of profit sharing is banking services needed by the community and in Indonesia itself is regulated in Government Regulation No. 72 of 92 concerning Banks Based on the Principle of Profit Sharing [2]. The main function of a profit-sharing bank is as a mediator between owners of capital or funds who wish to deposit funds in the bank (funding) and customers who need capital (financing).

The syari'ah banking system offers a more profitable bank financing option for the small and medium-sized business sector, where the risk of losing capital due to economic turmoil and so on does not have to be borne solely by the borrower. The syari'ah banking system offers fair financing based on the spirit of risk sharing and business results equally. 
In carrying out institutional functions so that the operations of Islamic banks do not deviate from the guidance of Islamic shari'ah, a Shari'ah Supervisory Board has been formed where the institution does not exist in conventional banking [2]. Banking institutions must be able to manage the financing they distribute. If the bank cannot manage it properly, it will greatly affect the progress of the bank itself.

A common risk faced by banks is the failure of the debtor to repay the financing installments. Transactions in which there are elements of fraud that are prohibited by the syara', such as transactions that occur between an Account Officer and a financing customer, here the Account Officer is a bank personnel engaged in product marketing. Financing that has been provided to customers must be carried out in accordance with the applicable financing procedures and internal bank regulations. Therefore, it is necessary to have supervision and guidance by the Account Officer to prevent information asymmetry [3]. This information asymmetry can be detrimental to the bank, because there is a possibility that the financing that has been given is used by the customer not in accordance with the proposed financing.

The emergence of information asymmetry can affect the size of the investment income carried out. The asymmetric form of agent information is usually in the form of moral hazard and adverse selection [4]. Adverse selection occurs in debt contracts when the quality of the borrower is only able to provide returns beyond the specified limit, while moral hazard occurs if the borrower reacts differently to contracts that have been agreed upon [5]. Therefore, syari'ah banks really need the role of an Account Officer in the supervision and guidance of financing customers. This effort is needed to avoid problematic financing.

\section{Literature Review}

\subsection{Account Officer}

Account Officer is a bank officer who in carrying out his work tries to create a mixture of various products and services tailored to market needs. An Account Officer has a role to foster customers in order to get efficiency and optimization of every financial transaction carried out without leaving his / her responsibilities as bank personnel. Account officers must be able to bridge the possibility of using the most suitable product for customers and monitor loans given to customers [6].

\subsection{Murabahah}

Murabahah is a sale of goods or sale and purchase of goods at the original price with an additional profit agreed between the bank and the customer [7]. The amount of the additional profit can be stated in a certain nominal rupiah or as a percentage of the purchase price. Murabahah contract is a form of natural certainty contract, because murabahah determines how much the required rate of profit is.

\subsection{Problematic Financing}

Non-performing financing does not appear immediately but generally goes through a period where various aspects of the customer have gradually decreased and ends with the customer's inability to pay the financing during that period. Several indications indicate the emergence of financing problems and banks must immediately take security steps to prevent the problem from getting worse. It is very possible that a financing that initially did not show a 
problem since the beginning of the gift suddenly became problematic without a signal of any kind of result [8].

\section{Methods}

This research is a field research with the aim of finding answers to existing problems [9]. The research location was conducted at one of the banking institutions in Indonesia, namely Bank Mandiri Syariah, Bandar Lampung City Branch. The population of this research is all customers who use murabahah financing products as many as 120 customers, while the research sample is 30 customers by distributing questionnaires.

\section{Result and Discussions}

The process of realizing financing in Islamic Banks is not as smooth as imagined, because not all customer characteristics are the same as one another. The involvement of Bank Syairah officials (Account Officer) in monitoring and supervising financing is a necessity that must be done. This is done to save public funds that have been mandated by Islamic banks. In addition, the supervision and guidance of Bank Syariah Mandiri Bandar Lampung financing customers is carried out by Account Officers to avoid delayed repayments or problematic returns. If something like this happens, the bank can experience a loss where financing is the main source of bank income.

The results of the study show that the coaching carried out by the account officer has an influence on the return of financing by customers with murabahah contract financing. This is shown from the results of the $t$ test of 5.261 so that the $t$ count is 5.261 . Then, the value of $t$ table itself is 2.048 so that $t$ count is greater than $t$ table $(5.261>2.048)$. Thus the results of the $\mathrm{t}$ test show that in Bank Mandiri Syariah in the city of Bandar Lampung itself there is a relationship or influence between coaching by the Account Officer and returns by customers for murabahah financing.

\section{Conclusion}

Research conducted at Bank Mandiri Syariah, Bandar Lampung City shows that the development of the Account Officer has an influence on the return of financing by customers with a contract or murabahah products as indicated by t table>t count. So this shows that in managing murabahah financing products it would be better if Bank Mandiri Syariah through an Account Officer to provide guidance to customers so that the refund rate can be on time and do not experience payment failures.

\section{References}

[1] C. Paun, "The Impact of Financial Sector Development and Sophistication Sustainable Economic Growth," J. Sustain., vol. 11, no. 1, 2019.

[2] W. Suminto, Analisis Ruang Lingkup Wewenang dan Tanggung Jawab Account Officer dalam 
mengantisipasi pembiayaan bermasalah, I. Jakarta: Raja Grafinto Persada, 2002.

[3] Jogiyanto, Teori Portofolio dan Analisis Investasi, 3rd ed. Yogyakarta: BPFE, 2000.

[4] Muhammad, Lembaga-lembaga Keuangan Kontemporer, I. Yogyakarta: UII, 2000.

[5] Muhammad, Konstruksi Mudarabah Dalam Bisnis Syari'ah. Yogyakarta: PSEI, 2003.

[6] J. Jusup, Panduan Dasar untuk Account Officer, 3rd ed. Yogyakarta: Yogyakarta Publisher, 2004.

[7] A. Maulidizen, "Literature Study on Murabahah Financing in Islamic Banking in Indonesia," Economica, vol. 9, no. 1, pp. 25-49, 2018.

[8] M. Ali, Pembiayaan Bermasalah Analisa, Penyelamatan dan Penyelesaian. Bandung, 1999.

[9] N. Indriartono, Metodologi Penelitian Bisnis Untuk Akuntansi dan Manajemen. Yogyakarta: BPFE, 1999. 